

JPE (2017) Vol.20 (2)

Shuaib-Babata, Y. L., Abegunde, A. J., Abdul, J.M.

Preliminary Note

\title{
SUITABILITY OF ADO-EKITI (NIGERIA) NATURAL MOULDING SANDS FOR USE AS FOUNDRY SANDS IN PRODUCTION OF ALUMINUM ALLOY CAST
}

Received: 22 September 2017 / Accepted: 12 November 2017

\begin{abstract}
Adequate application of sand casting processes in Aluminum casting can improve the economic activities of Nigeria through industrialization. Samples of natural moulding sand were collected from three different moulding sand deposits within Ado-Ekiti metropolis. The samples' properties were evaluated using American Foundry Society standards. The samples were used to produce aluminum alloy cast specimens and their mechanical properties were evaluated. The results revealed that the properties compared favourably with standard values as indication that the moulding sands are suitable materials for aluminum casting. Thus, effective application of the sample sands will enhance industrialization, job creation and the nation self-reliance.
\end{abstract}

Key words: Aluminum, casting, foundry, moulding and sand

Primenljivost ado-ekiti (Nigeria) prirodnog peska za livenje, upotreba peska za podlogu u proizvodnji aluminijumskih livenih legura. Adekvatnom primenom procesa livenja aluminijuma u pesku se može poboljšati ekonomske aktivnosti Nigerije kroz industrijalizaciju. Uzorci prirodnog livenog peska sakupljeni su iz tri različita depozita peska za livenje unutar Ado-Ekiti metropoli. Osobine uzoraka ocenjivane su korišćenjem standarda American Foundri Societi. Uzorci su korišćeni za proizvodnju livenih uzoraka legure aluminijuma i procenjena su njihova mehanička svojstva. Rezultati su pokazali da su osobine pozitivno upoređene sa standardnim vrednostima kao indikacija da je pesak za kalupovanja odgovarajući materijali za livenje aluminijuma. Stoga će efikasna primena peskovitih uzoraka poboljšati industrijalizaciju, otvaranje novih radnih mesta i samopouzdanje nacije.

Ključne reči: Aluminijum, livenje, podloga, kalupovanje i pesak

\section{INTRODUCTION}

Foundry technology is one of the vital bases for rapid industrial development of any nation. Rapid industrial development is very essential to positively address the problem of economic recession in Nigeria. Sand cast is found suitable in casting of all metals of different sizes, ranging from very small to extremely large sizes $[1,2]$. Sand is used in sand casting as a manufacturing process to produce a mould in which molten metal is poured to produce a cast. This is due to the fact that the sand particle size is packed finely and tightly together in such a way to provide excellent surface for the mould [3]. In manufacturing of engineering goods, tools, devices and equipment (such as engine blocks, machine tool bases, cylinder heads, pump housings, and valves), metal casting process is employed. In metal casting, sand casting is the most widely used [4]. Sand casting is found to be relatively cheap and adequate refractory for use in foundry applications [2]. Adequate utilization of sand as a resource will help towards enhancement of Nigeria's industrialization. Thus, rapid production of different locally needed devices, tools, utensils and equipment in Nigeria can be achieved through indigenous small and medium scale enterprises. Rapid growth in production was earlier reflected in the rising importance of manufacturing in the economies of virtually all countries [5].

Industrialization greatly depends on production capacity from availability of locally available raw materials used in development of technology in the transformation of the raw materials to finished products [6]. Hughes also identified the bases for the development of an industrial sector to include access to raw materials, labour force, funds and technology [7].

Raw Material Research and Development Council (RMRDC) in 1990 delved into geological survey of Nigeria resources and found sand to be the major mineral deposits in the country [8]. Sand covered an estimated proven reserve of billions of tones, out of which petroleum, gas and coal resources exploration had only received sufficient attention [9]. Studies have shown that majority of the available natural sands in Nigeria have not been receiving sufficient attention $[10$, $11,12,13,14]$.

Researchers had discovered through their various studies that most Nigerian Moulding sands, such as Azare foundry sand, Alkaleri, Barkin-ladi and Ilorin moulding sands were suitable for foundry applications $[13,15,16]$. Thus, it is essential to investigate the suitability of various Nigerian moulding sands for casting applications.

Shuaib-Babata and Olumodeji noted that the strength of foundry rests on the fundamental behaviour of sand, since casting quality depends on sand quality [13]. Sand often determines the quality of cast [17]. The choice of moulding sand for casting processes depends on its properties, such as strength, permeability, refractoriness, collapsibility [18].

Foundry sands were abundantly available and scattered all over the towns and villages in Nigeria 
which had been in use for past decades for casting of aluminum cooking utensils, decorative ornament and others without any evidence or trace of determining the mechanical properties or carrying-out any effect of sand on the product cast [13]. Hence, it is very essential to investigate the suitability of natural moulding sands in Ado-Ekiti (Nigeria) for Aluminum casting for its effective and appropriate usage in enhancing production of equipment, devices and home utensils, and at long run assist in solving the problem of unemployment in Nigeria.

Aluminum, the most abundant metal in the earth's crust is widely used as results of its excellent qualities $[19,20]$. Aluminum is known with high strength-toweight ratio, high thermal and electrical conductivity, high toughness with good strength at low temperature, high resistant to corrosion, non-toxic, excellent reflector of radiant energy, ease to form and fabricate, low weight, bright colour, and readily recycled [19, 20, 21]. It is also the lightest metal other than magnesium, with a density of about one-third of that of steel. These qualities made the material to be considered most suited for wide usages in transportation vehicles (such as aircraft, rocket, trucks, ships, automobiles), suitable structures (like ladders, scaffolding, gangways), heating and cooling applications (automobile radiator, refrigerator evaporator coils, heat exchangers, engine components), piping and vessels, cooking utensils, food processing and packaging of food and beverages, heat and lamp reflectors and for cryogenic vessels.

Scraps of Aluminum alloys (such as automobile engine piston scraps, cooking utensils, in dry-battery cell, among others) are commonly seen as waste products in major towns and villages in Nigeria. This material can be recycled to be used as raw material for aluminum casting in producing different items.

Application of sand casting processes in Aluminum casting can improve the economic activities of the country through industrialization, most especially during the present economic recession which requires shifting attention from over dependency on oil and gas as main economic source.

There is no doubt that the efficient and economic production of quality sand castings in the modern foundry requires a thorough knowledge of foundry sand technology [22]. This can be appropriately achieved through effective testing and analysis of sand mould in casting of device or any product; and analysis of the cast product properties. This study therefore is to determine the suitability of Ado Ekiti moulding sands for Aluminum casting and investigate the cast desirable properties and effectiveness in meeting appropriate casting materials' standards. Information from this study will at long run will enhance industrialization, job creation and the nation self-reliance through reduction in importation of foundry sand and Aluminum products into the country.

\section{MATERIALS AND METHODS}

\subsection{Materials}

The sand samples for this study were collected from Oke Ureje river banks (Sample A), Omisanjana river bank (Sample B) and Odo Ayo river bank (Sample C) within Ado-Ekiti metropolis. Ado-Ekiti is located in Ekiti state of Nigeria; situated in between longitude $5^{0}$ $11^{\prime}$ and $5^{\circ} 25^{\prime}$ and latitude $7^{0} 11^{\prime}$ and $7^{0} 37^{\prime}$.

Aluminum alloy scraps (Automobile engine piston) were obtained within Ado-Ekiti, Ekiti State, Nigeria and analysed at National Geosciences Research Laboratory, Kaduna, Nigeria.

\subsection{Methods}

\subsubsection{Preparation of natural moulding sand}

The sand samples collected from the above named locations were washed, sun-dried, filtered in order to separate the debris that was collected with them and kept in desiccators for further laboratory/experimental analysis, in accordance with American Foundry Society (AFS) standards. The details of the procedures had earlier been discussed [2].

\subsubsection{Production of sand specimens for laboratory analyses}

Sands obtained from the four selected sites were dried naturally to remove the free water and the specimens were prepared from each samples of the sand from these locations. A quantity of the sand was sieved through $2 \mathrm{~mm}$ British Standard (BS) sieve to obtain grain size required for the experiment. The sand grains pebbles were broken into pieces using foundry flat edge rammer, the powdered-moulding sand were thoroughly mixed with clean water for about 10 minutes to have homogeneous sand water mixture and sieved with $2 \mathrm{~mm}$ British standard sieve. The samples were then moulded in a specimen tube to produce standard test specimen of diameter $50 \mathrm{~mm}$ by average height of $85 \mathrm{~mm}$ using standard sand rammer that delivered a compaction blow of $6.4 \mathrm{~kg}$ thrice from a height of $50 \mathrm{~mm}$. The specimens were classified for various foundry tests. In accordance with the American Foundry-Men Society standards, AFS guidelines [23], the sands' foundry properties were obtained and recorded.

\subsubsection{Determination of chemical and Physico- mechanical properties of the natural moulding sands}

The chemical constituents of the samples of the sand samples were determined using $\mathrm{x}$-ray fluorescence (XRF) spectrometer and atomic absorption spectrophotometer (AAS). The Physic-mechanical properties of the moulding sands (such as moisture content, clay content, flowability, bulk density, permeability, shatter index, Compression strength, Green compression strength of natural moulding sand, dry compression strength, hot compression strength, refractoriness value of moulding sand) were also determined in line with AFS recommendations [23] and the details of the procedures were adequately discussed Shuaib-Babata and Abegunde [2].

\subsubsection{Melting and Casting Processes}

Pattern of the shape of object to be produced was made with core box. The sands prepared for analysis were made into moulds and filled into a wooden 
rectangular box prepared (molding). The pattern was pressed into the fine sand mixture to form the mold into which aluminum was to be poured. The pattern was made to be larger than the part to be made to give room for aluminum shrinkage during solidification and cooling. Cores were inserted into the casting box and properly set, after the pattern was removed. Gating/feeding system was then created to direct the metal into the mold cavity created by the pattern.

Melting of the aluminum alloy scraps was done using a fuel-fired crucible furnace for more than one hour at temperature of $700{ }^{\circ} \mathrm{C}$ and held at the temperature for 30 minutes to attain homogeneous composition. The melt was stirred and the mould was filled by pouring the melted aluminum from transfer ladles. It was allowed to cool thoroughly. The sand mold was then broken and casting was removed. The cast was then cleaned by removing the gates and risers, adhering sand, scale, parting fins and other foreign materials. Grinding of the object was carried out and subsequently inspection and testing to detect defects in the casting to attain better surface finishing and dimensional precision of the cast. The processes involved in the sand casting (production) of the aluminum cast (melting, casting and fettling processes) are as shown in Plates 1 - 3 .

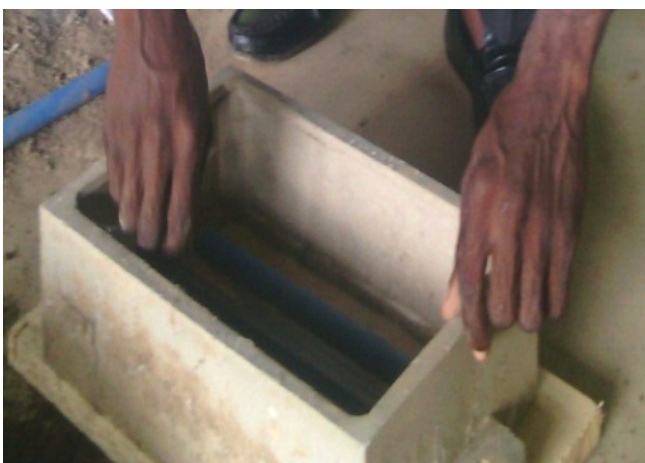

(a) Placing of pattern on the moulding board

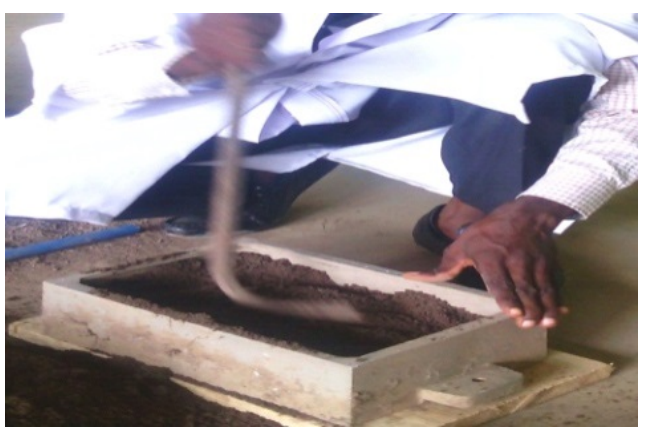

(b) Filling and ramming of mould

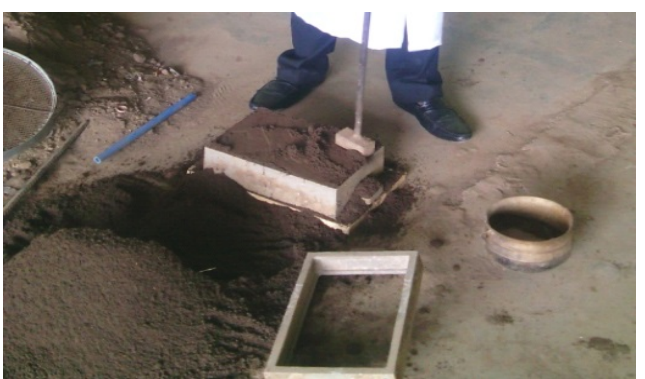

(c) Top filling of the drag

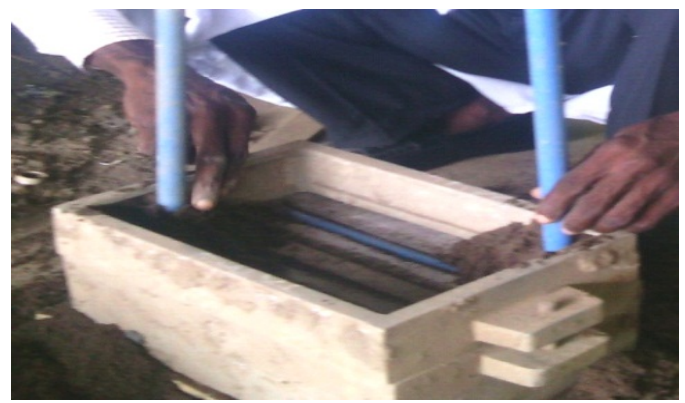

(d) Placing of cope over drag.

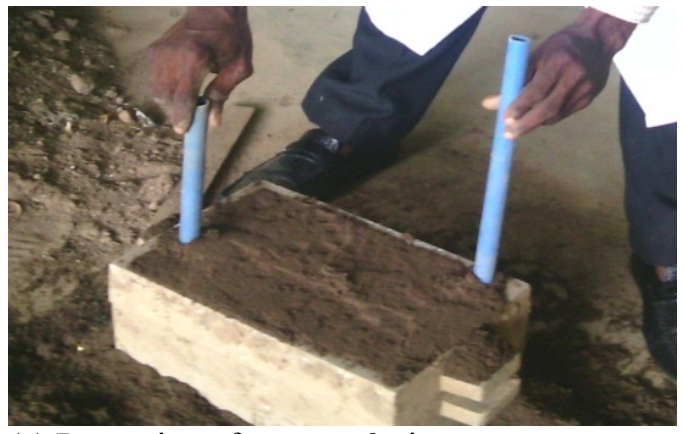

(e) Removing of runners \& riser

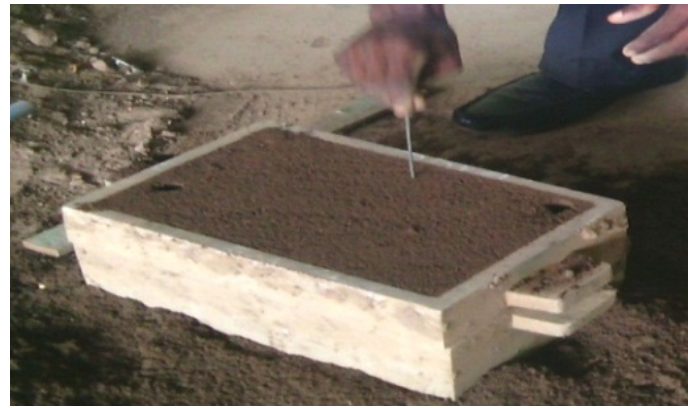

(f) Venting of the mould.

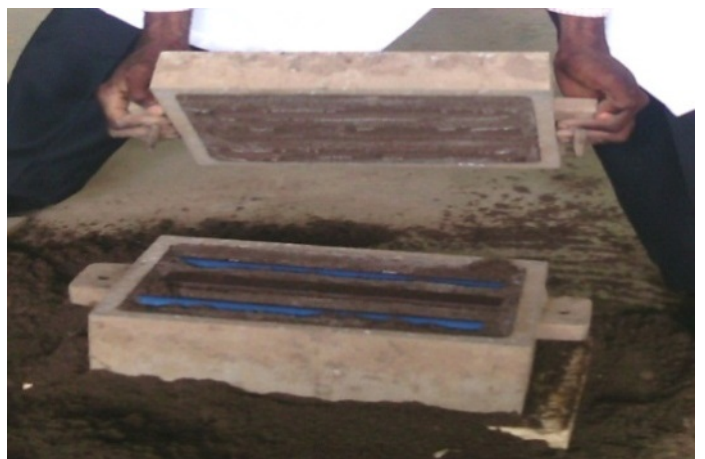

(g) Opening to remove patterns

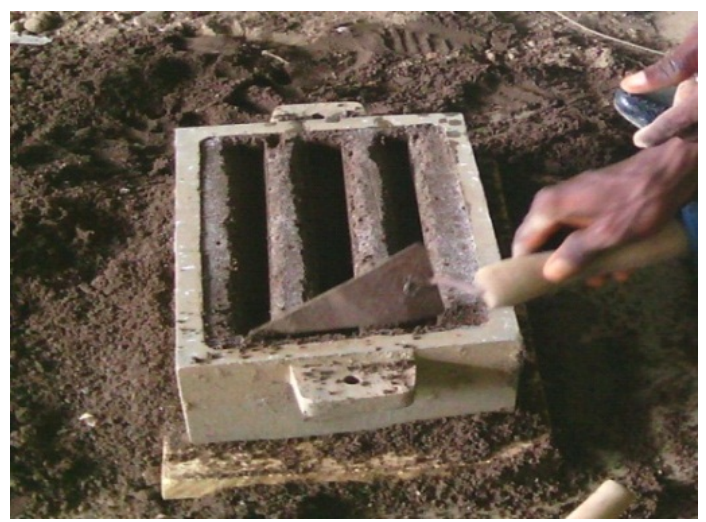

(h) Dressing and gating of the mould 


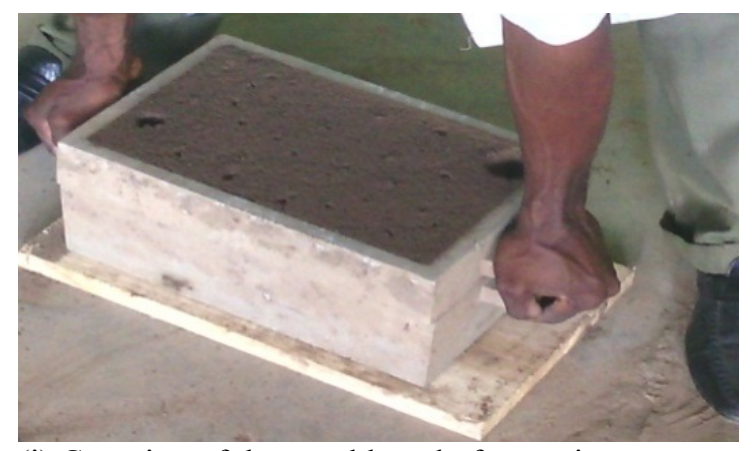

(i) Covering of the mould ready for casting

Plate 1. Preparation of mould for casting aluminum

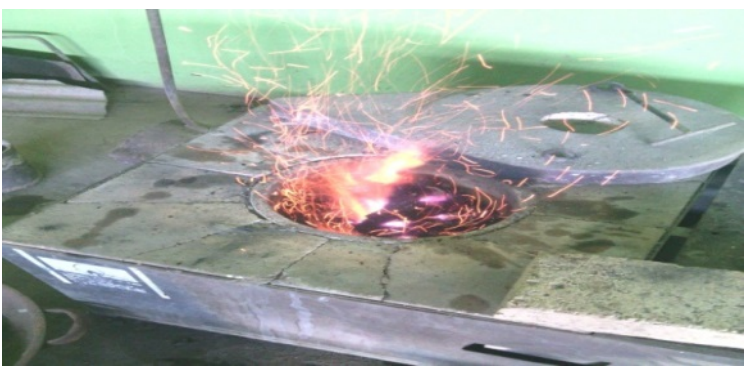

(a) Preparation of Furnace

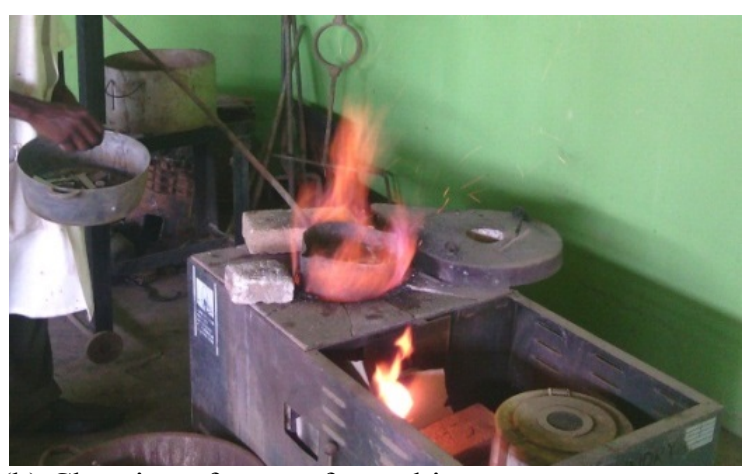

(b) Charging of scraps for melting.

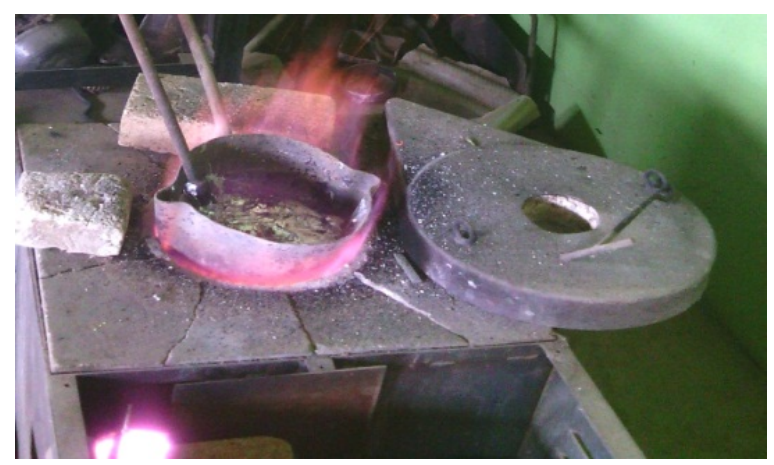

(c) Addition of fluxes

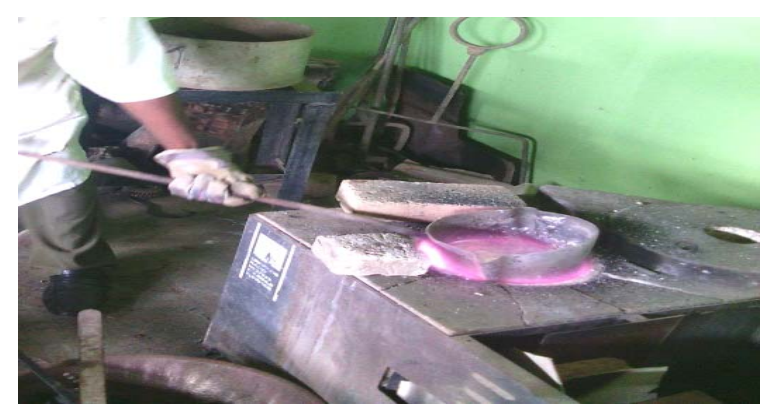

(d) Removing of molten metal from furnace Plates 2. Melting of Metal



(a) Pouring of Molten Metal

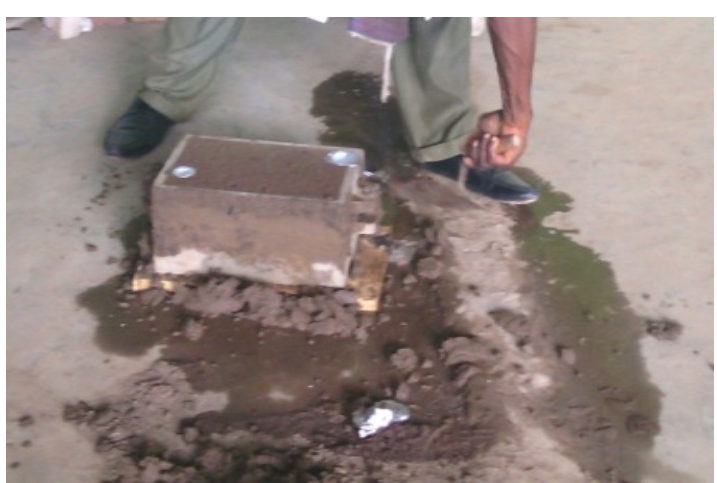

(b) Mold Filled with Molten metal.



(c) Removal of cast product

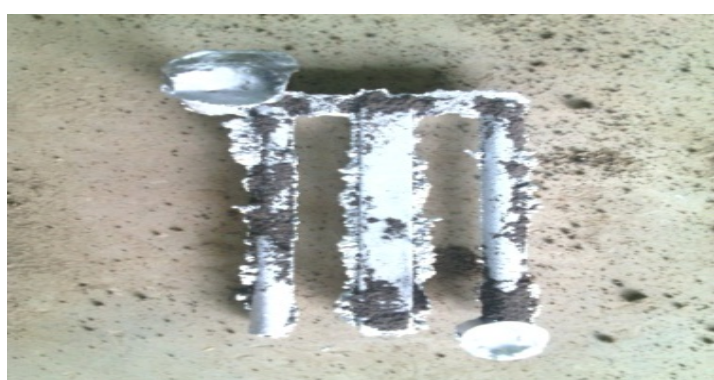

(d) Cast sample

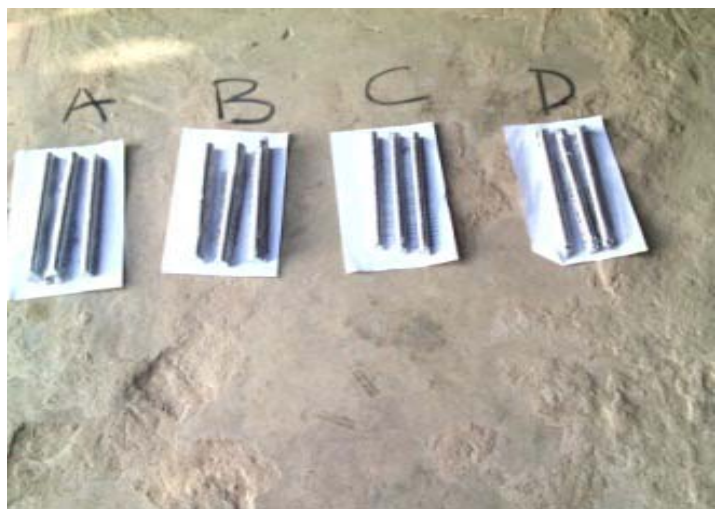

(e) Fettled casts.

Plates 3. Casting of mould. 


\section{DETERMINATION OF TENSILE STRENGTH AND HARDNESS OF THE CAST ALUMINUM SAMPLES}

The tensile specimens were prepared to required ASTM E-8 standard $[24,25]$ shape and sizes $(50 \mathrm{~mm}$ gauge length) as shown Plates 4 . The tensile properties of the specimens were determined on a Testometric Materials Testing Machine (Model 0500-10080, Win test analysis; $100 \mathrm{kN}$ capacity, England made) showing in Plates 5 and 6.



Plates 4. Specimens for tensile test

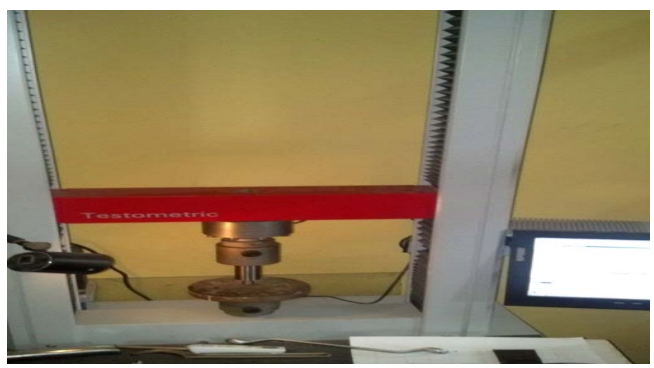

Plate 5. Testometric Materials Testing Machine Used

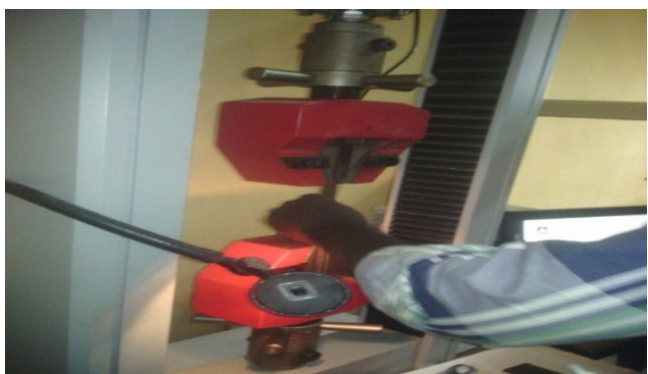

5.a) Fixing of a specimen unto the tensile testing machine

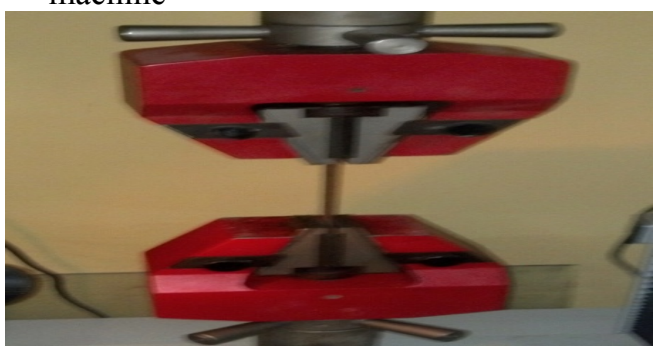

5.b) Specimen fixed in the UTM for tensile test
The hardness test was also done using each of the four samples of cast aluminum on the Tensometeric Materials Testing Machine. The surfaces of the machined specimens were ground to remove the skin or scale present on them. A hardened steel ball is pressed for a time of 10 to 15 seconds into the surface of the material with the Testometric machine but using another gripping device. After the load and ball have been removed, the diameter of the indentation was measured. The Brinell hardness number, signified by HB, was obtained and read on the computer screen attached to the machine

\subsection{Determination of impact strength value of cast aluminum}

The Charpy impact test, also known as the Charpy $\mathrm{V}$-notch test is the form used in this analysis. Test pieces which were machined to $60 \mathrm{~mm}$ long and 10 square millimeters notched on the notching machine; principally to assure fracture by a stress concentration introduced at the notch area (Plates 6).

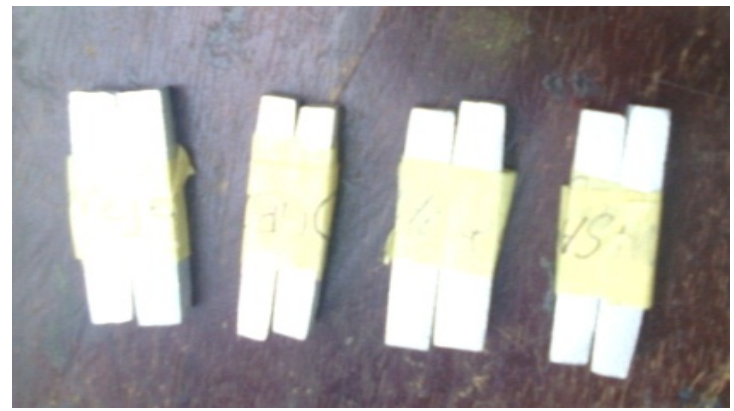

(a) Test pieces in different sizes



(b) Notching of test piece

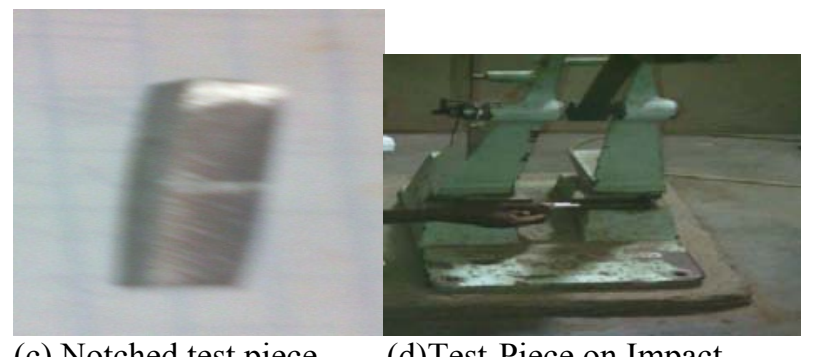

(c) Notched test piece

(d)Test-Piece on Impact machine

Plates 6. Impact Test

The notched specimen was fed into impact machine. The notched in the sample was of regular dimensions and geometry. The standard machine has the pendulum hitting the test piece with energy of $300 \pm 10 \mathrm{~J}$. The test 
piece was supported at each end with the notched side face directly opposite to where the pendulum strikes the test piece in line with the view of Bolton [23]. The specimens were fixed one after another to receive the fast moving hammer blow when released from a fixed height on the machine. Upon released, the pendulum hammer struck and fractured the specimen at the notched region.

\section{MICROSCOPIC STRUCTURE OF CAST ALUMINUM}

The micro examination of the cast pieces was carried out in accordance with the practice of Dibiezue using $2 \%$ of trioxonitrate $(\mathrm{v})$ acid as an etchant and viewed from metallurgical microscope of magnification X50.

\section{RESULTS AND DISCUSSION}

The results of chemical composition analysis for the selected moulding sands in Ado-Ekiti are as presented in Table 1. This result is significant since at the foundry, the chemical composition of the foundry sand relates directly to the metal moulded [26].

Table 1 revealed that the sample sands are of high proportion of silica, with $75.22 \%-79.23 \%$ silicon oxides, which are within the American Foundry Society, AFS standard. According to AFS, most metal casting sand (foundry sand) is high quality silica with physical characteristics [27].

The results of the physico-mechanical properties of the selected natural moulding sands in Ado-Ekiti are presented in Table 2.

\begin{tabular}{|c|c|c|c|c|c|c|c|c|c|c|c|}
\hline \multirow{2}{*}{ Sample } & \multicolumn{10}{|c|}{ Elemental Composition by Weight (\%) } \\
\cline { 2 - 11 } & $\mathbf{S i O}_{\mathbf{2}}$ & $\mathbf{A l}_{\mathbf{2}} \mathbf{O}_{\mathbf{3}}$ & $\mathbf{C a O}$ & $\mathbf{M g O}$ & $\mathbf{N a}_{\mathbf{2}} \mathbf{O}$ & $\mathbf{F e}_{\mathbf{2}} \mathbf{O}_{3}$ & $\mathbf{T i O}_{\mathbf{2}}$ & $\mathbf{K}_{\mathbf{2}} \mathbf{O}$ & $\mathbf{M n O}$ & $\mathbf{L O I}$ \\
\hline $\mathrm{A}$ & 78.67 & 12.20 & 0.35 & 0.40 & 1.87 & 1.69 & 1.76 & 0.17 & 1.89 & 0.81 \\
\hline $\mathrm{B}$ & 75.22 & 16.03 & 3.70 & 1.54 & 1.14 & 0.64 & 0.23 & 0.22 & 0.15 & 0.76 \\
\hline $\mathrm{C}$ & 79.23 & 12.20 & 0.35 & 0.40 & 1.80 & 1.66 & 1.75 & 0.13 & 1.72 & 0.75 \\
\hline
\end{tabular}

Table 1. Chemical Composition of Natural Moulding Sand

\begin{tabular}{|c|c|c|c|c|c|c|c|c|c|c|c|}
\hline 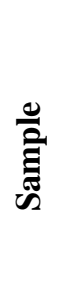 &  & 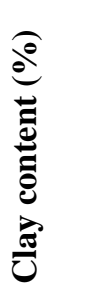 & 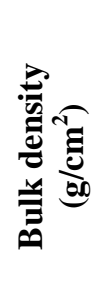 & 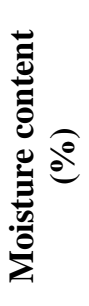 & 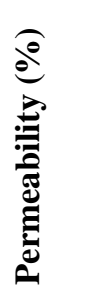 &  & 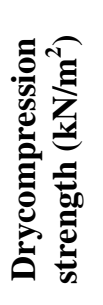 & 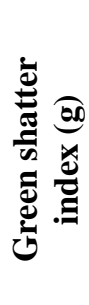 & 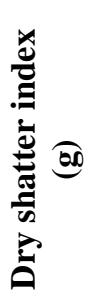 &  & 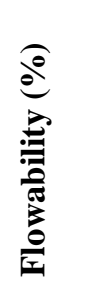 \\
\hline A & 63.27 & 12.0 & 12.04 & 7.36 & 86.2 & 120.9 & 203.0 & 0.50 & 0.22 & $>1200$ & 67.87 \\
\hline B & 61.08 & 13.0 & 12.25 & 5.75 & 87.5 & 63.6 & 101.8 & 0.03 & 0.05 & $>1200$ & 68.50 \\
\hline $\mathrm{C}$ & 66.98 & 10.0 & 12.23 & 6.79 & 86.3 & 70.9 & 191.0 & 0.12 & 0.30 & $>1200$ & 67.40 \\
\hline
\end{tabular}

Table 2. Some properties of the natural moulding sand samples

The result of AFS GFN analysis for the various specimens is presented in Table 2, which is a useful parameter with the average grain size of the sand with which its choice should be based on particle size distribution [28]. The values of the sand samples AFSGFN are within the standard ranges values of 35 to 90 fineness number for non-ferrous metal [29]. Sand with AFN $50-60$ with average grain size of $220-250$ microns and fines content (below 20 microns) 2\% maximum yields good surface finish at low binder levels; allows low binder level to be used; and allows low binder levels [30].

The samples' clay contents range between 10 and $13 \%$, an indication that the natural molding sand is expected to contain sufficient amount of binder material [31]. The specified clay content for moulding sand is between $10-12 \%$ [32]; while American Foundrymen's Association satisfactory proved values for aluminum, brass and bronze, iron and steel castings is between 12 and $18 \%$ clay contents [32].

Moisture content is the amount of water present in the moulding sand. In Table 2, the percentages of the moisture contents of the specimens are between 5.75 and $7.36 \%$, which are within the satisfactory AFS moulding sand moisture content for various types of castings [29].

The specimens' flowability values are between 67.25 and $68.50 \%$. It varies in sand with moisture and clay contents [31]. The AFS satisfactory mould sand percentage flowability for casting aluminum is 65 $[33,34,35,36]$. The high flowability value in the sands is as a result of rounded grains nature of the sand, which enhances the ease compaction of the sand [37]. Flowability increases with decrease in grain size of sand [31].

The permeability test results recorded for the tested natural moulding sands range between 86.2 and 87.5. The experimental results of the green permeability for the specimens in Table 2 indicate that the sand samples had good natural green permeability for casting a good number of ferrous and non-ferrous metals [32]. The recommended green permeability for green sand is within $80-110$ [28]. This implies that the study sands green permeability values are within the stated standard ranges. The high permeability is due the amount of well spread grain distribution and rounded-grains of the sand. The permeability depends on grain size, grain shape, grain distribution, binder 
and its content, degree of ramming and water content of the moulding sand the $[3,31,38]$.

Ureje sand with the highest moisture of $7.36 \%$ has the lowest \% permeability (86.2); Omisanjana sand sample with $5.75 \% \mathrm{MC}$ also possess the highest \% permeability of 87.5 . while Odo Ayo sand sample has $6.79 \% \mathrm{MC}$ and $86.3 \%$ permeability. The trend of these results is in line with the principle that high moisture content (MC) decreases permeability [39].

The green and dried shatter index of the specimens ranges between $0.03-0.50$ and $0.05-0.22$ respectively as shown in Table 2. The shatter index values also indicate that the sand samples are tough enough to aid satisfactory lift during pattern withdrawal. The content of clay and corresponding moisture content are attributed to this high value [16].

The sands' bulk density values are 12.04, 12.25 and $12.23 \mathrm{~g} / \mathrm{cm}^{3}$ for sample $\mathrm{A}, \mathrm{B}$ and $\mathrm{C}$ respectively. These values are within the recommended AFS specification [16]. Ihom et al. also gave recommended bulk density for green moulding sand as $1.49 \mathrm{~g} / \mathrm{cm}^{3}$ and above [28].

Moisture (MC) in moulding sand has influence on the sand permeability. High moisture content decreases permeability [39]. Moisture content affects the other properties of the mixture such as strength [40]. It was made known that too much moisture can cause steam bubbles to be entrapped in the metal casting. Though, there was opinion that low moisture content in the moulding sand does not develop strength properties [39].

Compression strength of natural moulding sand is the ability of the sand casting mixture to hold its geometric shape under the conditions of mechanical stress imposed during the sand casting process is the sand's strength [40]. Dry compression strength is the strength of the moulding sand in dry condition. The natural sand's dry compression strength increases as the moisture content of the sand increases [28]. The OkeUreje, Omisanjana and Odo Ayo sand samples exhibited dry compression strength values of 203, 101.8 and $191.0 \mathrm{kN} / \mathrm{m}^{2}$ respectively. The results in Table 2 show that the higher the $\mathrm{MC}$, the higher the dry compression strength. This is in line with the Ihom et al [28]'s assumption that dry compression strength increases with the MC of sand. The sand's strength depends on the clay and water content, type of clay, the clay size distribution, among other factors [28].

Green compression strength is the strength of the sand in the green or moist condition. A mould having adequate green strength will retain its shape; it will not distort or collapse even after the pattern has been removed from the moulding box. It helps in making and handling the moulds unless the mould is hardened in contact with pattern surface, it will not be possible to achieve dimensional stability and high accuracy of the required size. Oke-Ureje, Omisanjana and Odo Ayo sand samples exhibited green compression strength values of $120.9,63.5$ and $70.9 \mathrm{kN} / \mathrm{m}^{2}$ respectively. The recommended green sand's strength ranges between $70-100 \mathrm{kN} / \mathrm{m}^{2}$ [28]. The sand samples possess adequate green strength that will retain its shape and will not distort or collapse even after the pattern has been removed from the moulding box, but Omisanjana moulding sand's strength may needs to be enhanced.

\subsection{Chemical composition of aluminum scrap}

The chemical composition of the aluminum alloy obtained from scraps is presented in Table 3.

\begin{tabular}{|c|c|c|c|c|c|c|c|c|}
\hline Element & Al & Fe & Si & Mg & $\mathrm{Cu}$ & Zn & $\mathrm{Cr}$ & LOI \\
\hline \begin{tabular}{|c|} 
Percentage \\
Composition \\
$(\mathrm{Wt} \%)$
\end{tabular} & $\begin{array}{l}n \\
\infty \\
\infty \\
\infty\end{array}$ & $\begin{array}{l}8 \\
\stackrel{0}{0} \\
\end{array}$ & $\underset{0}{\infty}$ & ָे & ণ̦ & $\stackrel{\text { ô. }}{0}$ & స̄ & $\vec{m}$ \\
\hline
\end{tabular}

Table 3. Elemental chemical composition of the Aluminum alloy

\subsection{Mechanical Tests Results}

Sands used in casting of metals are proved to have effects on the cast alloy's properties due to the conditions the cast subjected to. Since the strength of these casts rest on the fundamental behavior of the foundry sand that was basically used in making the moulds and cores [13].

Aluminum alloys that were cast by these various sands were made into laboratory specification and subjected them to various mechanical tests.

Table 4 shows some tensile properties of the Aluminum alloy cast samples, while the hardness test results are graphically presented in Figure 1. The properties such as yield strength, ultimate tensile strength, plastic deformation limit and toughness are important, most especially for design engineers to determine the quantity of force the material can withstand with reference to the cross-section used without deforming permanently.

\begin{tabular}{|c|c|c|c|c|c|c|c|c|c|}
\hline$\sum_{\infty}^{\infty}$ & 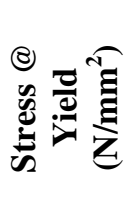 & 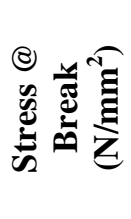 & 莤 & 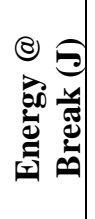 & 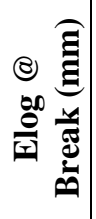 & 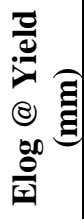 & ()ㅜㄹ & 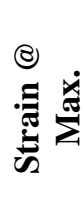 & 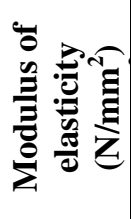 \\
\hline $\mathrm{A}$ & 1.9 & 1.9 & 1.8 & 6.4 & 66.0 & 5.0 & 2.1 & 2.0 & 35.0 \\
\hline $\mathrm{B}$ & 5.0 & 1.7 & 1.7 & 6.6 & 74.0 & 5.0 & 3.8 & 4.0 & 85.0 \\
\hline $\mathrm{C}$ & 5.7 & 2.2 & 2.2 & 10.0 & 61.0 & 5.0 & 2.1 & 2.0 & 83.0 \\
\hline
\end{tabular}

Table 4. Some mechanical properties of cast Aluminum samples

As presented in Table 4, the aluminum cast samples from Oke Ureje (moulding sand A), Omisanjana (moulding sand B) and Odo Ayo (moulding sand C) respectively are with tensile strength average values of 
1.9, 1.7 and $2.2 \mathrm{~N} / \mathrm{mm}^{2}$; while with the Ultimate tensile strength values are $1.8,1.7$ and $2.2 \mathrm{~N} / \mathrm{mm}^{2}$ and average ductility (elongation) values of 66,74 and $61 \mathrm{~mm}$ for sample $\mathrm{A}, \mathrm{B}$ and $\mathrm{C}$ respectively. The aluminum cast samples $\mathrm{A}, \mathrm{B}$ and $\mathrm{C}$ respectively also exhibited average toughness (the amount of the energy absorbed before failure) of $6.4,6.6$ and $10.0 \mathrm{~J}$.

The average Brinell hardness number $(\mathrm{BHN})$ of the cast aluminum samples from various tested moulding sands as presented in Figure 1 are 116.9, 101.9 and 114.1 BHN for cast from Oke Ureje (moulding sand A), Omisanjana (moulding sand B) and Odo Ayo (moulding sand $\mathrm{C}$ ) respectively. These values fall within AFS standard value ranges of $100-120 \mathrm{kN} / \mathrm{mm}^{2}$ [17].

\subsection{Microscopic Structure of Cast Aluminum}

The metallographic results showing microstructure of aluminum alloy casts are presented in Plates 7.
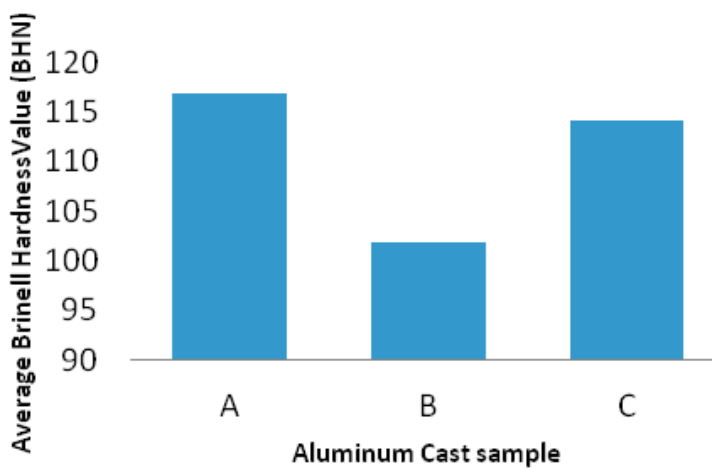

Fig. 1. Average Hardness of the Aluminum Cast from the Moulding Sand Samples

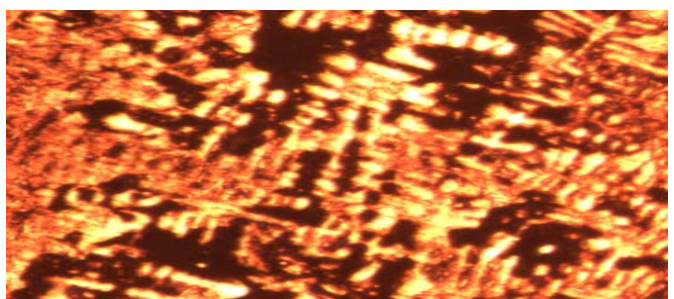

a) Oke Ureje (Sample A) x 50



b) Omisanjana (Sample B) x50



c) Odo Ayo (Sample C) x 50

Plates 7. Microscopic Structure of Cast Aluminum samples

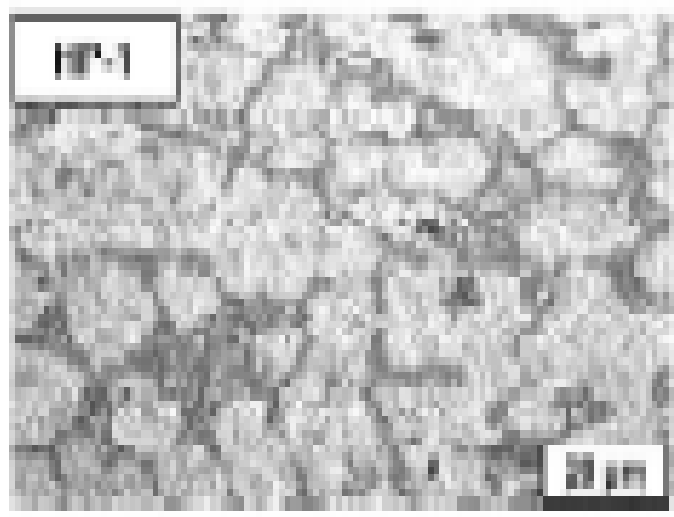

Plate 8. The microstructure of un-treated Al-7Si alloy [41]

The microstructures generally consist of fine crystals of aluminum (Al), magnesium silicide $\left(\mathrm{Mg}_{2} \mathrm{Si}\right)$ and $\mathrm{Al} \mathrm{Mg}_{2} \mathrm{Si}$ phases. Interestingly, the microstructure of un-treated Al-7Si alloy from a literature [41] that consists of large primary $\alpha-\mathrm{Al}$ grains is favorably compared with the microstructures of the cast aluminum samples.

\section{CONCLUSION}

From this study the following conclusions are drawn:

i. The chemical and physico-mechanical properties of the studied natural moulding sands were compared with AFS mould sand properties for casting of low meting temperature metals

ii. The sands had the potential for use in sandcasting process for non-ferrous metals.

iii. The properties of the aluminum casts from the sand samples were favourably compared with standard ranges for aluminum alloy cast from sand moulding process. This study therefore revealed that all the sand samples at green state were suitable for casting of aluminum alloy.

iv. Ekiti State in Nigeria has potentials of foundry sands and has to take the advantage with suitable conversion technologies.

\section{REFERENCES}

[1] Sand casting for manufacture - manufacturing process, Retrieved from http://thelibraryofmanufacturing.com/metalcastin g sand.html, accessed on February 22, 2017.

[2] Shuaib-Babata, Y. L., Abegunde, A. J. and Ambali, I. O.: Evaluation of chemical and physico-mechanical properties of Ado-Ekiti (South West, Nigeria) natural moulding sands for foundry applications, Arid Zone Journal of Engineering, Technology and Environment (AZOJETE), Vol. 13, No. 4, 2017, accepted for publication.

[3] Aweda, J. O., Jimoh, Y. A.: Assessment of properties of moulding sands in Ilorin and Ilesha, Nigeria, USEP: Journal of Research Information in Civil Engineering, Vol. 6, No. 2, pp 68-77, 2009. 
[4] Sand Casting. Retrieved from: http://thelibraryofmanufacturing.com/metalcasting sand.html, accessed on 22 January, 2017.

[5] Industry: Producing more with less, Report of the World Commission on Environment and Development: Our Common Future, Retrieved from: $\quad$ http://www.un-documents.net/ocf$\underline{08 . h t m}$, accessed on July 02, 2017.

[6] Chete, L. N., Adeoti, J. O., Adeyinka, F. M. and Ogundele, O.: Industrial Development and Growth in Nigeria: Lesson and Challenges, Leaning to Complete Working Paper No. 8, African Growth Initiative at Brookings Institute /African Development Bank Group / United Nations University UNU-Wider World Institute for Development. $\quad$ Retrieved from https://www.brookings.edu/wpcontent/uploads/2016/07/L2C_WP8 Chete-et-al1.pdf, accessed 0n August 22, 2017

[7] Hughes, J. R. T.: Industrialization. International Encyclopedia of the Social Sciences, Thompson Gale, Canada. Retrieved from http://www.encyclopedia.com/history/unitedstates-and-canada/us-history/industrialization\#B, accessed on July 02, 2017

[8] Raw Material Research and Development Council (RMRDC), $1^{\text {st }}$ ed, pp 18-22, 1990.

[9] Abegunde, A. J.: Analysis of moulding sand in Ado-Ekiti, Unpublished M.Eng Thesis, Ekiti State University, Ado-Ekiti, 2017.

[10] Abolarin M. S., Olugboji O. A. and Ugwuoke I. C.: Determination of Moulding Properties of Locally Available Clays for Casting Operations. Journal of AU Journal of Technology, Vol.9, No. 4, pp 238-242, 2006.

[11] Isah, B. K.: Solid Mineral Resource Development in Sustaining Nigeria's Economic and Environmental Realities of the 21st Century. Journal of Sustainable Development in Africa, Vol.13, No. 2, pp 210-214, 2011

[12] Adeoye, B.: Fallacy of Oil Wealth, Resource Curse and Economic Development: Oil Wealth and Income Inequality in Nigeria, Retrieved from https://adeoyebabatola.wordpress.com/2014/02/03/ fallacy-of-oil-wealth-resource-curse-andeconomic-development/, accessed on July 02, 2017.

[13] Shuaib-Babata, Y. L. and Olumodeji, J. O.: Analysis of Ilorin Sand Moulding Properties for Foundry Applications, International Journal of Engineering Research and Technology (IJERT), Vol. 3, No. 1, pp1520 - 1526, 2014.

[14] Ovat, F. A. and Bisong, M. A.: Analysis and categorization of Akparavini and Okwuboyere clay deposits in Biase LGA of Cross River StateNigeria. Engineering and Technology, Vol. 4, No. 2, pp16-21, 2017.

[15] Abolarin, M. S., Olugboji, O. A. and Ugwuoke, I. C.: Experimental Investigation on Local Refractory Materials for Furnace Construction, Proc. of the 5th Annual Engineering Conf., Federal University of Technology, Minna, Nigeria, pp. 8285, 2004.
[16] Tokan, A., Adelemoni, E. A. and Datau, S. G.: Mould Characteristics of Azare Foundry Sand, Journal of Raw Material Research (JORMAR), Vol.1, No. 1, pp 67-78, 2004.

[17] Nwajagu C. O.: Foundry Theory and Practice, $1^{\text {st }}$ Ed., ABC Publisher Ltd, Enugu Nigeria, pp. 418419, 1994.

[18] Bala, K. C. and Khan, R. H.: Characterization of Beach/River sand for foundry application, Leonardo Journal of Sciences, Vol. 12, Issue 23, pp 77-83, 2013.

[19] James, K. W.: Hanabook of advanced materials enabling new designs. A John Wiley \& Sons Inc., Publisher, New Jersey, 2004

[20] Degarmo, E.P., Black, J. T. and Kosher, R.: Mineral processes in manufacturing, McMillan, New York, 1988.

[21] Sanders, R. E.: Technology innovation on aluminum casting, Microsoft Corporation, United State of America, 2001.

[22] Le Serve F.L.: Sands and Sand Preparation, In: Beadle J.D. (Eds) Castings. Production Engineering Series. Palgrave, Londonhttps://doi.org/10.1007/978-1-34901179-7 5, accessed on Jyly 02, 2017.

[23] American Foundry-Men Society Standards (AFS): Mould and Core Testing Handbook, $2^{\text {nd }}$ Ed: Foseco Ltd Permgamon Press Oxford England, 1989.

[24] ASTM E8/E8M - 16a: Standard test methods for tension testing of metallic materials, ASTM International, West Conshohocken, PA, 2015.

[25] Bolton, W.: Engineering materials technology, $4^{\text {th }}$ ed., Butterworth-Heinemamn, Linnacre House, Jordan hill, Oxford, 2003.

[26] Akinyele, J.O. and Oyeyemi, K. S.: Strength Behaviour of Concrete using Foundry Sand as Aggregate, Journal of Natural Science, Engineering and Technology, Vol. 13, pp 99108, 2014.

[27] Introduction to foundry sand, Retrieved from: http://www.afsinc.org/content.cfm?ItemNumber $=7075$, accessed on August 27, 2017.

[28] Ihom, A. P., Agunsoye, J. Anbua, E. E. and Ogbodo, J.: Effects of Moisture Content on the Foundry Properties of Yola Natural Sand, Leonardo Electronic Journal of Practices and Technologies, Vol.9, pp 85-96, 2011.

[29] Burns T. A.: Foseco Foundryman's Handbook, $9^{\text {th }}$ ed, Foseco (F.S.) Ltd. Tamworth Staffordshire Permgamon Press Oxford England, pp 435, 1986.

[30] Tuncer, B. E.: Foundry Sand: Characteristics, Specifications, Environmental Considerations, Availability, Recycled Materials Resource Center (RMRC), University of WisconsinMadison, 2017.

[31] M E Mechanical. Molding Sand: Constituents, Types and Properties, Retrieved from https://memechanicalengineering.com/molding-sand/, accessed on July 02,2017

[32] Burns T. A. (Eds.): Foseco Ferrous Foundryman's Handbook. Butterworth 
Heinemann., New Delhi, India, pp. 1- 352, 1989

[33] Brown, J. R. (Ed.): Foseco ferrous foundry's man handbook, Butterworth, Heinemann, Oxford, 2000.

[34] Mikhailov, A. M.: Metal Casting, Mir Publishers, Moscow, 1989

[35] Ademola, N. A and Abdullah, A. T.: Assessment of Foundry Properties of Steel Casting Sand Moulds Bonded with the Grade 4 Nigeria Acadia Species (Gum Arabic). International Journal of Physical Sciences, Vol. 4, No 4, 238-241, 2009.

[36] Dielert, H. W.: Foundry Core Practice, American Foundry Men's Society. $3^{\text {rd }}$ Ed. Des Plaines Furnace lining. Nigerian Journal of Engineering Management. Vol. 2, No. 3, 1966.

[37] Casting and Welding: Lecture Notes on advanced casting and welding (ACW), SSM College of Engineering and Technology, Department of Mechanical Engineering. Retrieved from: https://ssmengg.edu.in/weos/weos/upload/EStudy Material/Mechanical/4thSem/productiontechonology/CastingAndWelding.pdf, accessed on May 25, 2017.

[38] http://www.iitbhu.ac.in/faculty/min/rajeshrai/NMEICT-Slope/lecture/c6/13.html), accessed on July 02, 2017.

[39] Mechanical Engineering: A complete online guide for every Mechanical Engineer-Sand testing methods sand testing equipment, Retrieved from http://www.mechanicalengineeringblog.com/299 7-sand-testing-methods-sand-testing-equipment/, accessed on July 02, 2017

[40] Sand Casting: Retrieved from: http://thelibraryofmanufacturing.com/metalcastin g sand.html, accessed on January 22, 2017.

[41] Choi, H., Konishi, H., \& Li, X.: Microstructure and mechanical properties of cast hypereutectic Al-Si alloy nanocomposites, Materials Science and -Technology Conference and Exhibition 2010, MS and T'10, pp692-701, 2010.

Authors: Senior Lecturer, Shuaib-Babata, Yusuf Lanre, PhD, PE, Department of Materials and Metallurgical Engineering, University of Ilorin, Ilorin, Nigeria Nigeria +2348033945977

Senior Technologist, Abegunde, Abayomi Johnson, M. Eng; Department of Mechanical Engineering, The Federal Polytechnic, Ado-Ekiti, Nigeria

Chief Lecturer, Abdul, Jimoh Mohammed, PhD, R.Eng, Federal Polytechnic, Offa, Nigeria

E-mail: sylbabata@gmail.com shuaib-babata.yl@unilorin.edu.ng 